\title{
PENINDASAN PADA BURUH PEREMPUAN INDUSTRI DI KOTA MEDAN PERSFEKTIF SPIVAK
}

\author{
Oleh: \\ Lukitaningsih
}

\begin{abstract}
ABSTRAK
Studi ini mengkaji penindasan buruh perempuan dari perspektif budaya patriaki. Dalam konteks ini dikaji diamnya buruh perempuan Industri disebabkan budaya patriarki dan ketimpangan gender, dan pengalamannya dalam memaknai penindasan. Penelitian ini dilakukan pada perusahaan industri yang ada di kota Medan, dengan metode kualitatif dan pendekatan etnografi feminis. Melalui metode ini diperoleh data dan informasi tentang pengalaman buruh perempuan yang mengalami penindasan. Hasil penelitian bahwa buruh perempuan mengalami penindasan disebabkan, pertama, budaya patriarki, meletakkan perempuan terdominasi dan tersubordi nasi dalam lingkup industri, struktur patriarki menempatkan laki-laki sebagai penguasa (dominan) di sektor industri. Bentuk patriarki yang dialami buruh perempuan di Industri Kota Medan adalah pelecehan seksual, perbedaan upah. Kedua, buruh perempuan mengalami penindasan disebabkan ketimpangan gender. Bentuk ketimpangan gender yang dialami seperti, tidak ada jaminan keselamatan saat bekerja, tidak mendapat tunjangan, tidak ada jenjang karir, status pekerjaan. Menurut Spivak perempuan yang mengalami penindasan di masyarakat tidak akan pernah mampu bersuara apalagi mendapatkan hak-hak sebagai warga negara pada masa kolonial. Penelitian ini menunjukan keadaan yang sedikit berbeda dengan teori Spivak, jika dalam penelitian Spivak perempuan India diam menerima penindasan yang dialami, perempuan buruh industri dapat bersuara atau menegosiasikan penindasan yang dialaminya.
\end{abstract}

Kata Kunci: penindasan, patriarki, ketimpangan gender, industri 


\section{PENDAhuluan}

Studi ini membahas tentang para buruh perempuan di sektor industri yang mengalami penindasan. Budaya patriarki dan ketimpangan gender menjadi penyebab dalam menjelaskan keadaan mereka. Selain itu, pengalaman yang mereka alami juga akan diungkapkan. Studi ini menjelaskan hubungan dominasi terhadap pihak yang tersubordi nasi dalam struktur kolonial tentang perbedaan kelas, antara penguasa dan yang dikuasai. Dalam kaitannya dengan struktur kolonial di sektor industri, maka pengusaha sebagai pihak dominan dan buruh perempuan sebagai pihak yang ter-subordinasi. Di mana pengusaha membangun suatu mekanisme dan sistem patriarki dalam menjalankan keberlangsungan perusahaannya. Sehingga buruh perempuan harus patuh pada aturan yang diberlakukan oleh perusahaan.

Di Indonesia, kasus penindasan kaum buruh perempuan kerap dilakukan oleh oknum pemilik modal. Adapun penindasan antara lain seperti pelanggaran hak maternitas, upah, sistem rekrutmen, pelecehan seksual, jam kerja, pemecatan setelah cuti melahirkan hingga keguguran di tempat kerja. Hal ini biasanya dialami oleh buruh perempuan yang bekerja di sektor industri. Pengusaha melakukan penindasan terhadap buruh perempuan dalam bentuk beban kerja yang berat, jam kerja yang panjang, pekerjaan yang penuh dengan resiko kecelakaan, tidak adanya perlindung reproduksi bagi buruh perempuan saat bekerja di pabrik, bekerja selama 7 jam dengan posisi berdiri, di sisilain buruh perempuan juga mengalami tindakan pelecehan seksual, dibedakannya upah buruh perempuan dengan buruh laki-laki, tidak tersedianya ruang laktasi, pelanggaran hak maternitas, pemecatan setelah cuti melahirkan hingga keguguran di tempat kerja.

Konsep dasar penindasan menurut Spivak (2010:78), melihat bagaimana hubungan dominasi terhadap pihak yang disubordinasikan dalam beberapa masyarakat bekas kolonial tentang persoalan perbedaan gender dan tekanan penguasa dalam kehidupan perempuan. Kondisi seperti ini menunjukan bahwa mereka yang berposisi dominan (pengusaha) memperlihatkan kekuatannya pada pihak lain (buruh perempuan), dan memelihara serta memperkuat ikatan emosional para penindasan 
(buruh perempuan) agar mematuhi aturan yang ada. Spivak mengkaji penindasan dari apa yang dilakukan oleh elite terhadap perempuan dari persfektif sosio-budaya, agama dan kebijakan publik.

Studi ini, bermaksud untuk mengkaji dan menganalisis buruh perempuan di sektor industri yang mengalami penindasan pada saat bekerja, dengan menggunakan teori feminis poskolonial konsep penindasan Gayatri Spivak. Studi tentang penindasan ini penting untuk dilakukan, karena tidak semata-mata mengkaji tentang buruh perempuan yang mengalami penindasan, diarea domestik dan industri. Apabila konsepsi penindasan dimaknai sebagai upaya menghadirkan pemaksaan melalui mekanismenya, maka mereka mengalami berbagai bentuk penindasan. Mekanisme ini berjalan secara halus dalam proses produksi sehingga yang didominasi tidak sadar, patuh dan menerima begitu saja.

Tujuan penelitian ini adalah : a) Mendeskripsi penindasan buruh perempuan di industri kota Medan disebabkan budaya patriarki dan ketimpangan gender.b) Memahami makna penindasan yang dialami oleh buruh perempuan di sektor industri dari persfektif Gayatri Spivak.

Untuk mencabar buruh perempuan di Industri digunakan teori feminis poskolonial dengan konsepnya penindasan dari Spivak.Teori feminis poskolonial, merupakan studi pertemuan antara feminis dan poskolonial. Studi poskolonial mencabar imperialis dan subjektivitas sedangkan studi feminis mencabar patriarki yang ada pada liberal dan imperialis dengan identitas, subyektivitas, agency. Studi feminis poskolonial berbicara mengenai kondisi suatu kaum yang tertindas oleh kaum yang dominan dalam lingkungannya dari sudut pandang Spivak. Ia lebih memberikan porsi pembahasannya tentang penindasan. Kajian Spivak tentang penindasan mencoba untuk membuka wacana terhadap perjuangan perempuan yang dijajah. Dalam konteks perjuangan politik dan perjuangan untuk mencapai keadilan merupakan sebuah penindasan yang dilakukan oleh kelompok yang mempunyai kekuasaan, kemudian kelompok ini bersatu untuk melawan kolonial atau penguasa. 
Menurut Gayatri Spivak penindasan adalah subjek yang tertekan,dan memi liki dua karakteristik :pertama adanya penekanan dan di dalamnya bekerja suatu mekanisme pendiskriminasian. Artinya bahwa penindasan tidak bisa memahami keberadaan dan tidak mampu untuk menyuarakan aspirasinya. Kedua penindasan tidak memiliki ruang untuk menyuarakan kondisinya, sehingga perlu kaum intelektual sebagai "wakil" mereka.

Proposisi yang dicabarkan oleh Gayatri Spivak adalah, (1) kondisi dari suatu kaum yang tertindas oleh kaum yang dominan dalam lingkungannya, (2) penindasan dan penciptaan atas dunia ketiga oleh negara kolonial, (3) masyarakat bekas jajahan sebagai dunia ketiga yang dieksplotasi tetapi memiliki warisan-warisan yang ditinggalkannya, (4) tidak ada ruang subyek penindasan untuk berbicara (5) menantang warisan kolonialisme dan budaya patriarki pada masyarakat di India pada waktu itu.

Studi subaltern yang dikembangkan oleh Spivak memiliki kelebihan sekaligus kontribusi yang sangat penting terutama terletak pada pendekatan dekonstruksi historiografi, yang menawarkan politik gender riset historis kajian subaltern, penemuan Spivak yang fenomenal tentang teori feminis poskolonial berasal dari kesadarannya akan posisi perempuan Hindu yang mengalami penindasan sebagai jenis kelamin liyan. Pemikiran Spivak memberi wacana bahwa perempuan mengalami penindasan, bahkan Spivak mengkritik orang yang tidak mampu berbicara merupakan orang bungkam dan mengatakan apabila seseorang tidak bisa berbicara dikategorikan sebagai orang yang mati.Menurut Spivak pembisuan menunjukan pada penindasan, terhadap semua perempuan di India.Wacana poskolonial Spivak untuk menyampaikan kebisuan disebutnya sebagai orang yang di tindas.

Bagi Spivak, bagaimana agar para subaltern bisa berbicara?.Suara dari para kaum tertindas tidak akan dapat dicari karena para kaum tertindas tidak bisa bicara. Kelompok-kelompok yang tertindas memang tidak bisa berbicara.Karena itu seorang intelektual tidak mungkin bisa mengklaim dan meromantisir kemampuan mereka untuk menggali dan mencari suara kelompok-kelompok tertindas. Klaim-klaim semacam ini justru bersifat kolonial, karena ia menyamaratakan (menghomogenkan) keberagaman 
kelompok-kelompok tertindas, dan pada akhirnya ia merupakan sebuah "kekerasan epistemologis" terhadap kelompok-kelompok tertindas.

Relasi yang tercipta antara korporasi (perusahaan) dengan kelompok (buruh perempuan) itu seperti relasi "tuan-hamba".perusahaan datang bukan buat mencari buruh perempuan, melainkan hadir sebagai penguasa atas kelompok-kelompok yang tertindas. Spivak menyarankan kaum intelektual seharusnya lebih banyak bertindak secara nyata untuk memperjuangkan kelompok-kelompok tertindas dari pada hanya berfikir atau berbicara saja.Teori ini juga melihat penindasan adalah istilah untuk kelompok tertentu di masyarakat yang berada di posisi paling rendah. Ia merupakan kelompok inferior, dan menjadi subjek hegemoni kelas-kelas yang berkuasa.

Penelitian ini menggunakan metode kualitatif,dan pendekatan etnografi feminis. pendekatan etnografi feminis mengisi kesempurnaan sketsa fenomena sosial dengan cara menggali peristiwa-peristiwa hidup perempuan, bukan hanya impian dan harapan tetapi juga ketakutan, stress, kelelahan dan pengetahuan lainnya. Pengalaman hidup buruh perempuan yang menjadi subyek dalam penelitian menjadi dasar konstruksi pengetahuan. Situasi emosi tidak perlu diingkari dalam pembentukan pengetahuan, dan pengalaman sebab dinamika relasi antara peneliti dan subyek turut menjadi momentum penting bagi pengembangan pengetahuan peneliti. Pendekatan ini memfokuskan pada pengalaman buruh perempuan sebagai subjek yang mengalami ketertindasan.

Lokasi penelitian dilakukan di industri, yang berada Kelurahan Tanjung Mulia Kecamatan Medan Deli Kota Medan. Tulisan ini akan menjelaskan buruh perempuan yang mengalami penindasan di karenakan budaya patriarki dan ketimpanangan gender pada sektor domestik oleh suami dan sektor industri atau publik, yang dilakukan oleh perusahaan, mandor, dan buruh laki-laki. Serta memahami makna ketertindasan yang dialami oleh buruh perempuan. 


\section{II.PEMBAHASAN}

Perusahaan Terbatas industri karet yang disebut dengan Deliwork didirikan pada tahun 1956 oleh badan usaha modal asing milik perusahaan Jepang. Perusahaan ini pada awalnya bergerak dalam industri peralatan rumah tangga yang bahan bakunya terbuat dari karet, seperti sarung tangan, sepatu, alas kaki, dan sebagainya. Dalam perkembangannya perusahaan industri karet tidak saja memproduksi kebutuhan rumah tangga tetapi sudah memproduksi jenis ban untuk kebutuhan kendaraan bermotor (seperti ban dalam, ban luar). Pengurangan peran negara terhadap perusahaan perusahaan swasta dilakukan melalui privatisasi (penguasaan oleh swasta/asing) atas sektor publik, hal ini terjadi karena seluruh perusahaan swasta sudah mengalami neoliberalm. Neoliberalisme sesungguhnya merupakan upaya pengurangan peran negara, artinya pengelolaan negara dikendalikan oleh korporat, (perusahaan swasta/asing). Akibat dari keputusan-keputusan politik tidak dibuat untuk kepentingan rakyat, tetapi untuk kepentingan perusahaan swasta baik domestik maupun asing.

Disisi lain, gelombang neoliberalis di segala bidang pasca reformasi, telah memberikan kesempatan kepada kekuatan kapitalis global untuk makin menancapkan pengaruhnya di Indonesia. Dengan bantuan dana dari investor asing dan swasta, mereka banyak mendapat kemudahan dalam kebijakan, peraturan perundangan yang sangat liberal di pengaruhi oleh kepentingan pihak swasta. Neo-liberalis menganjurkan penghapusan campur tangan pemerintah dalam urusan ekonomi. Tidak ada pembatasan untuk produksi pabrik, tidak ada pembatasan atas perdagangan bebas, tidak ada cukai. Penerapan usaha individual mendorong munculnya usaha bebas, persaingan bebas, yang berarti bebas bagi pemilik modal untuk mendapatkan keuntungan sebesarbesarnya.

Buruh perempuan yang bekerja di sektor industri mengalami penindasan disebabkan relasi patriarki. Sistem patriarki meletakkan perempuan tersubordinasi dalam lingkup keluarga dan pekerjaan di sektor industri dengan menempatkan laki-laki sebagai penguasa. Sistem patriarki sebagai salah satu kajian alternatif terhadaprelasi kuasa patriarki dalam kehidupan sosial, dalam bentuk : (i). Relasi patriarki produksi 
dalam level ekonomi, (ii) Relasi patriarki dalam pekerjaan ber-upah, (iii) Relasi patriarki dalam perusahaan(iv) relasi patriarki dalam pelechan seksual.

Relasi patriarki pada produksi level ekonomi di rumah tangga, bentuk yang sangat mendasar adalah relasi di mana dalam kerja 'diperlihatkan' kewajiban untuk bekerja. Kerja yang dilakukan oleh perempuan bisa disusun mulai dari memasak, mencuci, mengurus suami serta menjaga anak-anak. Perempuan sebagai istri melakukan pekerjaan tersebut untuk suaminya, istri tidak memperoleh upah dari pekerjaannya tersebut karena semua itu merupakan konsekuensi dari ikatan pernikahan. Suami bisa mengendalikan istri karena memiliki sifat maskulinitas yaitu kekuasaan atas istri mereka.

Pada level ekonomi dalam pekerjaan ber-upah, relasi patriarki dalam pekerjaan ber-upah,terlihat pada pemberlakuan dibedakannya penerimaan upah yang tidak setara, tidak adanya jenjang karier, tidak ada fasilitas reproduksi bagi buruh perempuan. Padahal jika dilihat pada aspek jam kerja, dan beban kerja keduanya memiliki durasi yang sama. Selain itu, ketimpangan ini tampak dari adanya pemusatan tenaga kerja perempuan pada bahagian produksi yang menempatkannya pada bidang-bidang yang lebih mengandalkan sisi tenaga yang besar, juga ketelitian, ketekunan buruh perempuan.Sektor ini dianggap oleh kebanyakan perusahaan sebagai pekerjaan yang mudah sehingga mereka dibayar dengan upah murah dibandingkan upah buruh lakilaki.

Pengaruh dari sistem patriarki adanya pembagian kerja berdasarkan jenis kelamin di mana pada masyarakat patriarki sektor publik dikaitkan laki-laki dan sektor domestik atau rumah tangga dikaitkan dengan perempuan. Dalam sistem masyarakat industrial dan kapitalis, segala sesuatu dinilai menurut nilai tukarnya di pasar, berdasarkan permintaan dan penawaran atau menjadi komoditi, termasuk manusia (laki-laki dan perempuan). Di sisi lain, dalam menekuni sektor publik dengan bekerja di industri karet deli memberikan konsekuensi tersendiri bagi perempuan. Disamping mendapatkan upah tentunya mereka juga harus memikul peran ganda (domestik dan publik) dalam kehidupan sehari - hari. Keadaan ini dapat menimbulkan eksplotasi bagi 
buruh perempuan. Di sisi lain kaum laki-laki sebagai orang yang bertanggung jawab mencari nafkah umumnya belum secara suka rela membantu istri melakukan pekerjaan rumah. Kultur patriarki mempengaruhi konstruksi sosial pada masyarakat. Perbedaan gender telah melahirkan berbagai ketimpangan, bagi perempuan, dalam bentuk subordinasi, marginalisasi, strerotipe, dan beban ganda. Bentuk-bentuk ketimpangan tersebut merupakan sumber utama terjadinya eksplotasi dan diskriminasi terhadap perempuan.

Penindasan pada buruh perempuan disebabkan oleh ketimpangan gender, ketimpangan gender adalah kondisi di mana terdapat ketidaksetaraan antara laki-laki dan perempuan dalam sektor publik. Bentuk ketimpangan gender yang dialami buruh perempuan di sektor industri dalam bentuk subordinasi, adalah buruh perempuan tidak bisa menduduki posisi sebagai kepala regu, mandor, kepala shif, dengan alasan buruh perempuan lemah, irasional, emosional, dan tidak terampil. Kemudian mereka juga mengalami marginalisasi, dalam perbedaan upah dengan buruh laki-laki, ketidaksamaan akses keuntungan, dan tidak adanya fasilitas reproduksi bagi buruh perempuan dalam bekerja. Selanjut nya mereka mengalami penindasan karena strerotipe, beban ganda.

Selain itu, buruh perempuan mengalami pelecehan seksual di tempat kerja, terjadi pada saat bekerja malam, siang, atau jam istirahat, bentuk pelecehan seksual yang diterimanya dalam bentuk gurauan-gurauan porno, menyentuh paha, buah dada, memberi komentar mengenai penampilan fisik, memeluk, memegang pinggang dan lainnya.

Meskipun demikian, para buruh perempuan tetap bekerja dan bertahan sebagai buruh di pabrik di sektor industri. Meskipun mereka dihadapkan pada persoalan marginalisasi, subordinasi, pelecehan seksual, diskriminasi, strerotipe, beban ganda dan ketidakadilan dalam pekerjaannya. Bahkan tidak sedikit diantara perempuan yang bekerja tersebut berstatus sebagai orang tua tunggal (single parent) yang berarti bahwa mereka berperan sebagai kepala keluarga. Pada kenyataannya dunia kerja seperti sektor 
industri justru menjadi wadah dimana terdapat kasus-kasus bersifat ketimpangan gender. Bagaimana tidak, perempuan banyak dibutuhkan tenaganya pada sektor industri selain dinilai mempunyai keuletan dan ketekunan melebihi laki-laki juga dinilai sebagai tenaga kerja kelas dua (second class).Perempuan dipandang lebih pasif karena bersedia menerima otoritas dan bersedia diberi upah sedikit.

Dalam can the subaltern Speak?, Spivak mengemukakan bahwa tidak mungkin bagi kita untuk menggali kembali suara subaltern atau subjek yang tertindas. Penindasan bagi Spivak berdasar pada biologis (perempuan), tidak ada ruang bagi mereka untuk bisa bersuara. Spivak melihat kepada pola perdebatan kolonial tentang bakar diri janda di India untuk melihat bagaimana pandangan bahwa gabungan caracara kerja kolonialisme dengan partiarki dalam kenyataanya menjadikan sulit bagi penindasan (dalam hal ini janda India yang dibakar hidup-hidup dalam api unggun pembakaran suaminya) untuk mengartikulasikan pandang annya. Perempuanperempuan India, dalam hal ini janda India, yang harus ikut mati dalam pembakaran suaminya yang meninggal ini tidak memiliki suara untuk menolak. Ia juga menulis kisah tentang bunuh diri Bhuvaneswari disebabkan tak mampu melakukan pembunuhan politik yang dipercayakan dalam kelompok perjuangan bersenjata.

Spivak juga mengemukakan pendapat bahwa gerakan feminis poskolonial yang memperjuangkan kesetaraan gender antara laki-laki dan perempuan telah melahirkan konsep-konsep tentang ketidakseimbangan hubungan antara laki-laki dan perempuan.Pada sistem ini laki-laki berperan menentukan apa yang boleh dan apa yang tidak boleh dilakukan kaum perempuan.

Pemikiran Spivak memberi wacana bahwa perempuan India mengalami penindasan dalam budaya, agama, politik. Bahkan Spivak mengkritik orang yang tidak mampu berbicara merupakan orang bungkam dan dikategorikan sebagai orang yang mati. Dalam hal ini Spivak melihat bahwa perempuan India tidak bersuara dikarenakan mengalami penindasan yang dilakukan oleh kelompok dominan seperti kaum brahmana, penguasa kolonial maupun penguasa lokal. 
Pada studi penindasan ini, buruh perempuan yang bekerja di sektor industri mengalami ketertindasan di pabrik. Bentuk penindasan yang dialami menjadikannya sebagai pendorong untuk berani bernegosiasi, dan melakukan perlawanan kepada mandor, kepala regu dan buruh laki-laki sebagai perpanjangan tangan perusahaan. Di sisi lain perusahaan juga memberikan ruang bagi buruh perempuan untuk melakukan negosiasi dengan perusahaan, mandor, ketua regu, dalam bentuk tulisan (surat), lisan.

Menurut Spivak bahwa perempuan sebagai sosok tertindas dalam masyarakat tak akan pernah mampu bersuara apalagi mendapatkan hak-hak yang selayaknya sebagai manusia. Sebagai perempuan yang di subordinasikan secara kultural, agama, politik dan tidak dapat bertindak apalagi bersuara. Pada penelitian ini buruh perempuan yang mengalami subordinasi, marginalisasi, beban ganda, dan pelecehan seksual terkonstruksi sosial karena maskulinitas dan feminitas yang berlaku pada sektor industri.

Studi ini juga mengkritisi pemikiran Spivak yang memberi wacana bahwa perempuan diam dan tidak bersuara dikarenakan ketidakmampuannya melawan budaya patriarki yang melekat pada sistem budaya, agama, dan politik masa kolonial di India, Ia hanya melihat perempuan di India secara homogen mengalami penindasan dalam kehidupanya. Sedangkan pada studi ini buruh perempuan di sektor industri mengalami penindasan karena perlakuan dan tindakan dari perusahaan yang dilakukan oleh mandor, buruh laki-laki sebagai perpanjangan tangan perusahaan. Perlakuan dan tindakan penindasan yang diterima berupa perbedaan upah, kesejahteraan, fasilitas, pelecehan seksual, jenjang karier, sistem kontrak kerja. Di sisi lainnya perusahaan juga memberikan ruang bagi buruh perempuan untuk melakukan negosiasi bila tidak berkenan dengan apa yang mereka alami, ruang negoisasi diberikan dalam bentuk penyediaan kotak saran, bernegoisasi dengan perwakilan sarikat buruh Indonesia, yang ada di perusahaan.

Penelitian ini menunjukan keadaan yang sedikit berbeda dengan teori Spivak, jika dalam penelitian Spivak perempuan India diam menerima penindasan yang dialami, sedangkan buruh perempuan yang bekerja di sektor industri dapat bersuara 
atau menegosiasikan penindasan yang dialaminya. penindasan dapat diakhiri dengan membongkar konstruksi sosial tentang feminitas dan maskulinitas.

\section{PENUTUP}

Seiring dengan semakin berkembangnya sektor industri, buruh yang dibutuhkan juga bertambah banyak, sehingga mereka merekrut perempuan sebagai buruh. Kehadiran buruh perempuan sangat mewarnai dan sebagai urat nadi bagi industri karena jumlah buruh perempuan lebih banyak di bandingkan buruh laki-laki. Keadaan ekonomi yang sebenarnya menjadikan perempuan bekerja mencari nafkah. Sayang posisi tawar buruh perempuan rendah, meskipun begitu mereka tetap menekuni pekerjaan, selain tidak ada pilihan lain juga karena faktor sosial budaya yang ikut membatasi geraknya. Bagi perempuan yang belum menikah/berkeluarga, bekerja adalah untuk membantu orang tua, sedangkan bagi yang sudah berkeluarga bekerja ini merupakan suatu kegiatan penting untuk memenuhi kebutuhan hidup sehari hari.

Pengaruh dari budaya patriarki adanya pembagian kerja berdasarkan jenis kelamin di mana pada masyarakat patriarki sektor publik dikaitkan laki-laki dan sektor domestik atau rumah tangga dikaitkan dengan perempuan. Dalam sistem masyarakat industrial dan kapitalis, segala sesuatu dinilai menurut nilai tukarnya di pasar, berdasarkan permintaan dan penawaran atau menjadi komoditi, termasuk manusia (laki-laki dan perempuan). Di sisi lain, dalam menekuni sektor publik dengan bekerja di sektor industri memberikan konsekuensi tersendiri bagi mereka. Disamping mendapatkan upah, tentunya mereka juga harus memikul peran ganda (domestik dan publik) dalam kehidupan sehari - hari. Keadaan ini menimbulkan masalah pada ketimpangan gender, karena kaum laki laki sebagai orang yang bertanggung jawab mencari nafkah umumnya belum secara suka rela membantu istri melakukan pekerjaan rumah. Sistem patriarki sebagai salah satu kajian alternatif terhadap relasi kuasa patriarki dalam kehidupan social. 
Relasi patriarki produksi merupakan satu dari dua struktur patriarki yang berlangsung pada level ekonomi. Buruh perempuan dikendalikan oleh suami mereka dalam ikatan pernikahan dan hubungan rumah tangga. Bentuk yang sangat mendasar adalah relasi produksi di mana di dalamnya kerja 'diperlihatkan' dari pada kewajiban yang menggantikan kerja tersebut. Kerja yang dilakukan oleh perempuan bisa disusun mulai dari memasak dan mencuci untuk suami serta menjaga anak-anak. Perempuan sebagai istri melakukan pekerjaan tersebut untuk suaminya (dalam lingkungan tertentu, sebagai anak perempuan untuk ayahnya), istri tidak memperoleh upah dari pekerjaannya tersebut karena itu semua merupakan konsekuensi dari ikatan pernikahan.

Struktur patriarki kedua pada level ekonomi adalah relasi patriarki dalam pekerjaan dengan upah, relasi patriarki dalam pekerjaan ber-upah adalah penutupan akses oleh laki-laki untuk perempuan. Hal itu melibatkan dijauhkannya perempuan dari pekerjaan ber-upah atau pemisahan kerja-kerja perempuan di dalamnya. Kondisi itu menyebabkan rendah upah kerja bagi perempuan dibandingkan buruh laki-laki. Diskriminasi gender dalam pembagian kerja di luar konteks rumah tangga menyentuh hampir semua kerja produktif ekonomis yang dilakukan perempuan. Dalam sektor indutri, perempuan lebih dominan dipekerjakan sebagai buruh . Hal ini merupakan salah satu aspek dari pembagian kerja nasional yang sedang berubah, menuju pada aktivitas ekonomi perempuan yang ber-upah. Keterlibatan perempuan dalam kegiatan ekonomi di luar rumah mendekatkan perempuan pada penindasan, eksplotasi, diskriminasi yang dilakukan oleh laki-laki atau pengusaha.

Perusahaan melakukan patriarki sekaligus kapitalis. Sebagai arena perjuangan dan bukan sebagai entitas monolitis, perusahaan memiliki bias sistematis terhadap kepentingan patriarki seperti tampak dalam kebijakan-kebijakan dan tindakantindakannya yang berhubungan dengan kehidupan buruh di sektor industri. Relasi patriarki negara terhadap buruh perempuan di sektor industri adalah dikeluarkanya UU No.13 tahun 2003, dengan dikeluarkannya UU tersebut menguntungkan kalangan industriawan dimana sistem outsourcing, sub-kontrak merupakan suatu strategi 
manajemen yang sangat ampuh untuk mendapatkan keuntungan yang maksimal. Mekanisme outsourcing telah menjadi sebuah sistem perburuhan yang mengingkari hak-hak buruh khususnya buruh perempuan. Pratek sistem kerja kontrak semakin meluas dan hampir semua perusahaan atau industri saat ini memberlakukan kontrak kerja yang pendek dan outsourcing bagi sebahagian tenaga kerjanya.

Struktur patriarki dalam pelecehan seksual, adalah heterosek sualitas, Selain itu, buruh perempuan mengalami pelecehan seksual di tempat kerja, terjadi pada saat bekerja malam, siang, atau jam istirahat, di mana mandor, kepala regu dan buruh lakilaki menunjukan sikap maskulinitas terhadap buruh buruh perempuan. Tindakan maskulinitas dalam pelecehan seksual menempatkan sisi laki-laki yang sangat dominan menciptakan identitas perempuan menjadi makhluk kelas dua. Ini salah satu contoh relasi patriarki dalam pelecehan seksual yang dialami oleh perempuan, hal ini tidak lepas dari konsep nilai yang melihat bahwa perempuan itu sebagai feminis yang layak untuk mendapat godaan, dalam bentuk: pelecehan fisik, lisan, isyarat dan pelecahan seksual tertulis. seperti gurauan-gurauan porno, menyentuh paha, buah dada, memberi komentar mengenai penampilan fisik, memeluk, memegang pinggang dan lainnya.

Budaya patriarki menyebabkan terjadinya ketimpangan gender antara buruh lakilaki dan buruh perempuan dalam sektor industri, terutama mengenai penerimaan uang kesejateraan yang berbeda dengan buruh laki-laki, jenjang karier, fasilitas reproduksi bagi buruh perempuan. Padahal jika dilihat pada aspek jam kerja, keduanya memiliki durasi yang sama. Bentuk diskriminasi dan subordinsi yang diterima buruh perempuan adalah tidak ada jenjang karier, mereka tidak boleh menjadi mandor, kepala regu atau kepala shif, hal ini disebabkan karena konstruksi sosial peran maskulinitas dan peran feminitas. Jenjang karier hanya bisa diberikan kepada laki-laki karena lebih utama sedang perempuan menjadi kelas nomer dua. Sehingga perusahaan memandang bahwa pekerjaan yang berat sebagai mandor, kepala regu, dan kepala shif hanya dapat dikerjakan oleh buruh laki-laki yang mempunyai kekuatan, waktu yang banyak untuk bekerja di pabrik. Kemudian buruh perempuan juga mengalami marjinalisasi dengan 
tidak adanya fasilitas reproduksi yang tersedia di tempat kerja atau pabrik seperti ruang laktasi dan hak maternitas bagi mereka. Masyarakat dan laki-laki mengungkapkan bahwa perempuan hanyalah pencari nafkah tambahan bagi keluarga, sehingga walau beban menjadi buruh pabrik sangatlah berat, dan upah yang sedikit, hal itu dianggap wajar bagi laki-laki.

Semua bentuk ketimpangan gender berpangkal pada suatu kekeliruan tentang stereotipe gender laki-laki dan perempuan. Pemberian citra yang salah terhadap perempuan digunakan oleh kelompok maskulinitas sebagai alasan untuk membenarkan situasi suatu tindakan dari laki-laki kepada perempuan. Buruh perempuan karena konstruksi gender menyebabkan mereka harus berperan ganda. Beban pekerjaan yang diterima pada sektor domestik dan publik mengharuskan mereka mempunyai tenaga yang kuat. Walaupun mereka sudah bekerja di sektor publik atau industri tetapi mereka masih punya tanggung jawab di sektor domestik atau rumah tangga. Konstruksi maskulinitas dan feminitas pada buruh perempuan untuk beban kerja yang ganda harus dimiliki oleh buruh perempuan.

Makna penindasan yang dialami buruh perempuan karena ketimpangan gender antara lain, a) diterima dan ditolak karena ketidakadilan yang diciptakan dunia kerja khusus sektor industri. Bagaimana tidak, perempuan yang banyak dibutuhkan tenaganya pada sektor industri selain dinilai mempunyai keuletan dan ketekunan melebihi laki-laki juga dinilai sebagai tenaga kerja kelas dua (second class). Perempuan dipandang lebih pasif karena bersedia menerima otoritas dan bersedia diberi upah sedikit. Konstruksi gender menyebabkan buruh perempuan tetap bekerja untuk menghidupi keluarganya meskipun mereka dihadapkan pada persoalan marginalisasi, subordinasi, pelecehan seksual, diskriminasi, strerotipe, beban ganda dan ketidakadilan dalam pekerjaannya. Bahkan tidak sedikit diantara perempuan yang bekerja tersebut berstatus sebagai orang tua tunggal (single parent) yang berarti bahwa mereka berperan sebagai kepala keluarga. b) mereka ingin melawan bentuk penindasan tersebut tetapi di sisi lainya konstruksi feminitas yang melekat pada diri perempuan menyebabkan mereka tidak dapat berbuat banyak atau menerima, hal ini dilakukan 
karena mereka butuh uang untuk menghidupi keluarganya. Tidak saja berperan ganda, akan tetapi memiliki triple role ; yaitu peran reproduksi, yaitu peran yang berhubungan dengan peran tradisional disektor domestik (mengandung, melahirkan dan merawat anak), peran produktif, yaitu peran ekonomis disektor publik, domestik, dan peran sosial, yaitu sebagai warga masyarakat.

\section{DAFTAR BACAAN}

Achmad, Baso. (2005). Ke Arah Feminisme Postradisional. Jakarta: Desantara Ashcroft, Bill. (2003). Post- Colonial Transformation, London and New York: Routledge.

Baykan, Aysegul. (2000). Perempuan, Antara Fundamentalisme dan Modernisasi" dalam Bryan, Turner (ed). Teori-Teori Sosiologi : Modernitas dan Postmodernitas. Yogyakarta : Pustaka Pelajar

Bagong, S \& Emy, S (ed). (1996). Wanita dari Subordinasi dan Marginalisasi Menuju Pemberdayaan. Surabaya: Airlangga Universitas Press

Bourdieu, Pierre. (2010). Dominasi Maskulin (terjemahan). Yogyakarta: Jalasutra Press.

Boserup,Ester. (1991).Language and Symbolic Power.Cambridge: Polity Press

Brooks, Ann.(2011). Posfeminism: Feminism, Cultural Theory and Cultural Form, Yogyakarta : Jalasutra Press.

Budiman, Arief. (1982). Pembagian Kerja Secara Seksual. Jakarta : PT Gramedia

Denzin, Norman K dan Yvonna, S Lincoln (ed) (2011). The Sage Handbook of Qualitative Research 1 dan 2.Yogyakarta : Pustaka Pelajar.

Gandhi, Mahatma. (2011). Kaum Perempuan dan Ketidakadilan Sosial.Yogyakarta: Pustaka Pelajar.

Gandhi, Leela. (2001). Teori Poskolonial : Upaya Meruntuhkan Hegemoni Barat, Yogyakarta : Qalam.

Gidden, Anthony.(2002). Negara, Bangsa, dan Kekerasan. Jakarta : Ghalia Indonesia

Handayani,Sih,et.all.(1996). Mengkonstruksi Realitas dengan Perspektif Gender, Yogyakarta: SBPY Press

Juliet, Mitchell. (2000). Patriarchy and Matriarchy, Feminist Concepts Series, Bombay: SNDT

Morton, Stephen.(2008). "Spivak,Gayatri Etika, Subaltern dan Kritik Penalaran Postkolonial", (terj), Yogyakarta: Pararaton

Reinharz, Shulamit.(2005). Metode-Metode Feminis dalam Penelitian Sosial. Jakarta :

Women Research Institute

Saadawi, El Nawal,(2011). Perempuan Dalam Budaya Patriarki. Yogyakarta: Pustaka Pelajar

Sangeeta, Ray. (2009). Gayatri Chakravorty Spivak, Sang Liyan, (terj), Denpasar: Bali Media Adikarsa

Spivak, Gayatri Chakravorty. (2010)."Can the Subaltern Speak? Postkolonialitat und subaltern Artikulation. Chicago : University of Chicago Press . (2008). "Can the Subaltern Speak?". Dalam Bill 